\title{
K5/K14-positive cells contribute to salivary gland-like breast tumors with myoepithelial differentiation
}

Werner Boecker ${ }^{1,2}$, Goeran Stenman ${ }^{3}$, Thomas Loening ${ }^{4}$, Mattias K Andersson ${ }^{3}$, Agnes Bankfalvi ${ }^{5}$, Sarah von Holstein ${ }^{6,7}$, Steffen Heegaard ${ }^{6,7}$, Alina Lange ${ }^{1}$, Tobias Berg ${ }^{1}$, Vera Samoilova $^{1}$, Katharina Tiemann ${ }^{1}$ and Igor Buchwalow ${ }^{1}$

${ }^{1}$ Institute for Hematopathology, Reference Center for Gynaeco- and Breast-pathology, Hamburg, Germany;

${ }^{2}$ Gerhard-Domagk-Institute of Pathology, University of Muenster, Münster, Germany; ${ }^{3}$ Department of

Pathology, Sahlgrenska Cancer Center, University of Gothenburg, Gothenburg, Sweden; ${ }^{4}$ Albertinen

Pathology, Hamburg, Germany; ${ }^{5}$ Institute for Pathology and Neuropathology, University Hospital Essen,

Essen, Germany; ${ }^{6}$ Institute of Neuroscience and Pharmacology, Eye Pathology Institute, University of

Copenhagen, København Ø, Denmark and ${ }^{7}$ Department of Ophthalmology, Glostrup Hospital, København Ø,

Denmark

Salivary gland-like tumors of the breast show a great variety of architectural patterns and cellular differentiations such as glandular, myoepithelial, squamous, and even mesenchymal phenotypes. However, currently little is known about the evolution and cellular differentiation of these tumors. For that reason, we performed an in situ triple immunofluorescence lineage/differentiation tracing (isTILT) and qRT-PCR study of basal (K5/K14), glandular (K7/K8/18), and epidermal-specific squamous (K10) keratins, p63, and smooth muscle actin (SMA; myoepithelial marker) with the aim to construct and trace different cell lineages and define their cellular hierarchy in tumors with myoepithelial differentiation. isTILT analysis of a series of 28 breast, salivary, and lacrimal gland tumors, including pleomorphic adenomas $(n=8)$, epithelial-myoepithelial tumors $(n=9)$, and adenoid cystic carcinomas $(n=11)$ revealed that all tumor types contained K5/K14-positive progenitor cells in varying frequencies from a few percent up to $15 \%$. These $\mathrm{K} 5 / \mathrm{K} 14$-positive tumor cells were found to differentiate to glandular- (K8/18-positive) and myoepithelial-lineage (SMA-positive)-specific cells and were also shown to generate various heterologeous cell differentiations such as squamous and mesenchymal progenies. p63 was co-expressed with K5/K14 in basal-like progenitor cells, myoepithelial, and squamous cells but not in glandular cells. Our results show that the corresponding counterpart tumors of breast and salivary/lacrimal glands have identical cellular compositions. Taken together, our isTILT and RNA-expression data indicate that look-alike tumors of the breast represent a special subgroup of basal-type tumors with benign or usually low malignant potential.

Modern Pathology (2013) 26, 1086-1100; doi:10.1038/modpathol.2013.45; published online 5 April 2013

Keywords: keratin 5; keratin 14; p63; progenitor cells; salivary gland-like breast tumors; triple-immunofluorescence

A small proportion of benign and malignant tumors of the breast have a morphological appearance analogous to tumors of the salivary, lacrimal, and

Correspondence: Dr W Boecker, MD, Institute for Hematopathology, Immunohistopathology, Fangdieckstreet 75a, 22547 Hamburg, Germany.

E-mail: boecker@me.com

The authors dedicate this work to Prof. Dr Gerhard Seifert and the late Prof. Dr Dr.h.c.mult. Karl Donath-two great pioneers in salivary gland pathology.

Received 30 October 2012; revised 14 January 2013; accepted 14 January 2013; published online 5 April 2013 sweat glands. ${ }^{1,2}$ Altogether these tumors account for about $1 \%$ of all breast cancers. ${ }^{3}$ In contrast, these tumors are common in the salivary glands, accounting for as much as $60 \%$ of the tumors. ${ }^{4}$ These look-alike tumors include pleomorphic adenomas, epithelial-myoepithelial tumors, adenoid cystic carcinomas, mucoepidermoid carcinomas, adeno-squamous carcinomas, and others. They are characterized by a remarkable morphological heterogeneity both between and within individual tumors of both sites. Thus, different architectural patterns and cell populations with different phenotypes can 
be found including tumor cells showing glandular, myoepithelial, squamous, and mesenchymal phenotypes. ${ }^{4-8}$ However, the evolution of these lesions in both breast and salivary glands in terms of different lineage differentiations and cells of origin are still contradictory and poorly understood. Several authors have suggested that some of these tumors arise from a single cell with the potential for divergent differentiations. ${ }^{2,9,10}$ It has also been proposed that the myoepithelial cell might have a role in this context, at least in some of these lesions. ${ }^{2,11}$

In order to investigate this further, we have now analyzed a series of salivary gland-like tumors of the breast and their salivary/lacrimal gland counterparts, including pleomorphic adenomas, adenoid cystic carcinomas, and epithelial-myoepithelial tumors, using in situ triple immunofluorescence lineage/ differentiation tracing (isTILT) experiments, which allow direct observation of cells at different stages of differentiation. By tracing the sequential expression of basal (K5 and K14), glandular (K7 and K18, K8/18), and epidermal-specific squamous keratin (K10) ${ }^{12-14}$ in combination with p63 $3^{15,16}$ and discriminatory myoepithelial markers such as SMA, ${ }^{7,17-19}$ we can infer the developmental capacities of K5/K14-positive tumor cells and construct differentiation lineage trees for these tumor types.

The data presented here illustrate the cellular organization of look-alike tumors with myoepithelial differentiation of the breast and salivary/ lacrimal glands from a novel point of view. The full extent of K5/K14-positive tumor cells with their complex lineage differentiations can be appreciated and shown to be an important clue for the understanding of the evolution of these tumors. On the basis of our findings, we postulate that $\mathrm{K} 5 / \mathrm{K} 14$ positive progenitor cells contribute to the development and differentiation of these lesions and thus confirm their basal type nature.

\section{Materials and methods}

\section{Case Selection}

Routinely processed formalin-fixed paraffin-embedded tissues from 8 pleomorphic adenomas, 9 epithelial-myoepithelial/myoepithelial tumors, and 11 adenoid cystic carcinomas of the breast and their counterparts of salivary/lacrimal gland origin were retrieved from the consultation files of the Department of Pathology of the Muenster University (WB) and Albertinen Pathology, Hamburg/Salivary Gland Registry, Hamburg (ThL). All cases were reviewed at least by two pathologists independently (WB, ThL) and classified according to previously published criteria described in the WHO Breast Tumor Classification from $2012^{5,7,8}$ and the WHO Classification of Head and Neck Tumors. ${ }^{20-26}$ Normal human breast tissue obtained from plastic surgery and normal salivary glands were used as controls.

\section{Tissue Probe Processing and Primary Antibodies}

Paraffin tissue sections ( $4 \mu \mathrm{m}$ thick) were pretreated and stained as described elsewhere. ${ }^{27}$ For immunostaining, we used primary antibodies raised against keratin K5 (rabbit monoclonal, MEDAC Diagnostica), keratins K5/6, K14, K7, K8/18, K18 and K10 (mouse monoclonals, DAKO, Sigma and Dianova), SMA (rabbit polyclonal, Abcam), vimentin (mouse monoclonal, Abcam and DAKO), Ki-67 (Rabbit Monoclonal, Thermo Fisher Scientific), and p63 (DAKO). The exclusion of the primary antibody from the immunohistochemical reaction or substitution of primary antibodies with normal IgG (mouse or rabbit) at the same final concentration as that of the primary antibodies resulted in lack of immunostaining.

\section{Bright-field Microscopy}

Following the immunoreactions with primary antibodies, the sections were treated for $10 \mathrm{~min}$ with methanol containing $0.6 \% \mathrm{H}_{2} \mathrm{O}_{2}$ to quench endogenous peroxidase. For bright-field microscopy, bound primary antibodies were detected with Dako LSAB REAL Detection System (Naphthol phosphate/Fast Red, no. K5005, Dako Corporation, Hamburg, Germany) or with AmpliStain horseradish peroxidase (HRP) conjugate (SDT GmbH, Baesweiler, Germany) according to manufacturers' instructions. The HRP label was visualized using the NovaRed substrate kit (Vector Laboratories, Burlingame, CA, USA). The sections were counterstained with haematoxylin. All steps were preceded by rinsing with PBS ( $\mathrm{pH}$ 7.4).

\section{isTILT Experiments}

Systematic isTILT-experiments were performed for basal, glandular (luminal), and squamous keratins as well as for SMA. For these studies, we used secondary antibodies (purchased from Dianova and Molecular Probes) conjugated with Cy3, Alexa Fluor-488, Alexa Fluor-647, or with biotin. ${ }^{27,28}$ For simultaneous visualization of primary antibodies of the same IgG isotype, primary antibodies were non-covalently labeled with a reporter molecule in vitro employing monovalent IgG FC-specific Fab fragments. ${ }^{29}$ The reporter molecule was either fluorophore Cy3 or biotin. The latter was visualized using fluorophore-labeled streptavidin. Nuclei were counterstained with DAPI ( $5 \mu \mathrm{g} / \mathrm{ml}$ PBS, $15 \mathrm{~s})$, and sections were mounted with VectaShield (Vector Laboratories).

\section{Image Acquisition}

Immunostained sections were examined using a Zeiss microscope (Axio Imager Z1). Images were captured and processed using an AxioCam digital microscope 
camera and the software AxioVision image processing (Carl Zeiss Vision, Germany). The images were imported as JPEG files into PhotoImpact 3.0 (Ulead Systems, Torrance, CA, USA) and submitted with the final revision of the manuscript at $300 \mathrm{DPI}$.

\section{Quantitative RT-PCR (qPCR)}

Areas of tumor tissue were manually microdissected from tissue sections (WB). Total RNA was extracted from the microdissected tissue using the RNeasy FFPE kit (Qiagen, Germany). mRNA of keratins 5,
14, 7, 8, 18 and 10, and ACTA2 (alpha 2 SMA) was reverse transcribed and amplified using the OneStep RT-PCR kit (Qiagen, Germany). RNA expression was quantified by real time fluorescence detection of amplified cDNA (ABI life technologies, StepOne system) using MGB-probes. Gene expression levels are described as ratios between two absolute measurements (gene of interest/HPRT endogenous reference). All samples were run in triplicate for all genes. We compared the differential expression of 6 keratins (K5/K14/K7/K8/K18/K10) and ACTA2 in tumor and normal breast parenchyma or nipple squamous epithelium.
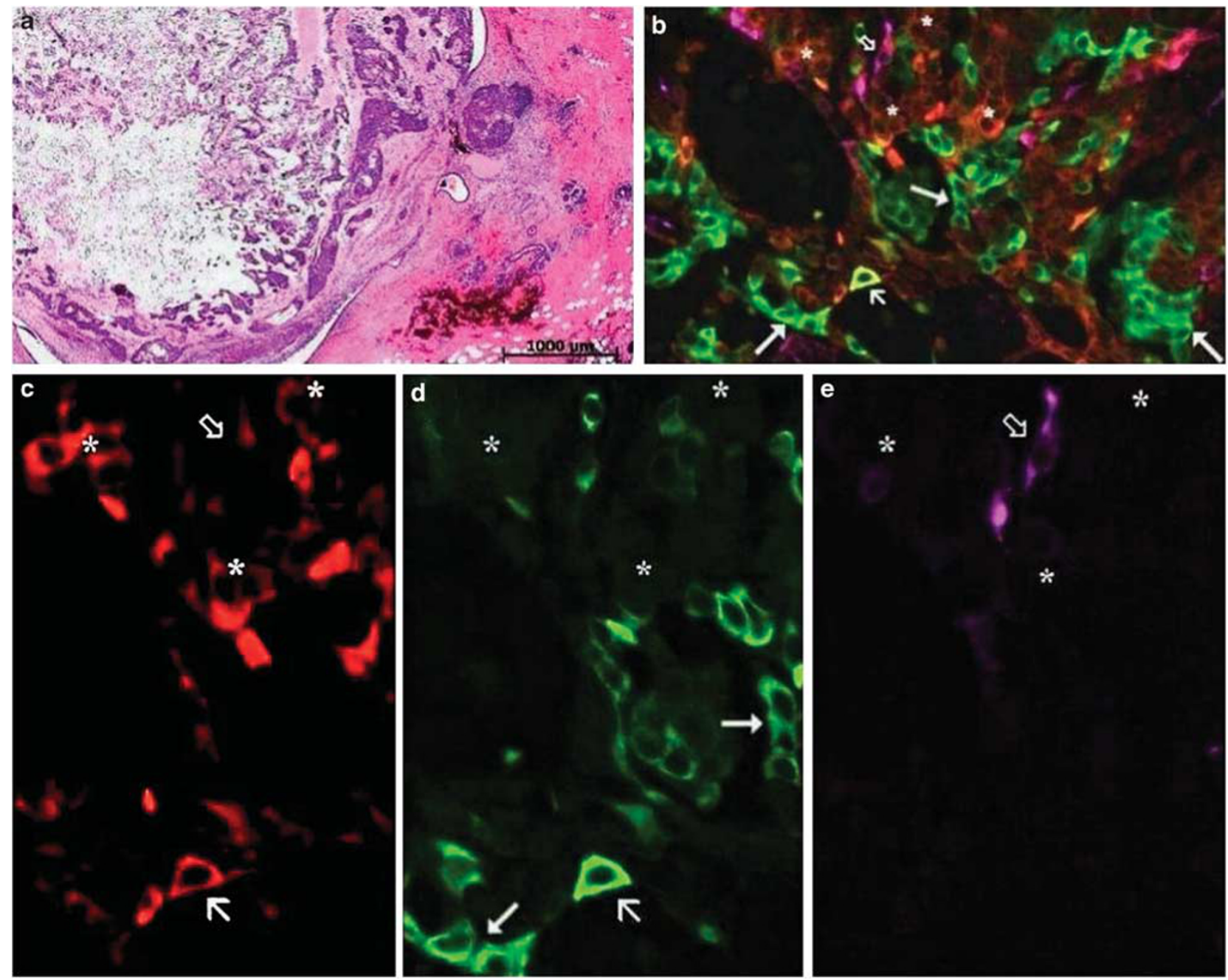

Figure 1 Pleomorphic adenoma of the breast. (a) H/E staining of a typical tumor with chondromyxoid matrix. Normal breast tissue with lobules is shown on the right; (b) isTILT for K5/6 (red), K8/18 (green), and SMA (pink) showing the cellular heterogeneity of the tumor; a moderate number of K5/6-expressing cells (red, asterisks) and K8/18-positive cells (green, long arrows) which are typically located in anastomosing cords of more cohesive epithelial cells; Note that there is only a small number of SMA-expressing cells (hollow arrow). (c-e) Small area of (b) with single channels demonstrating glandular and myoepithelial differentiation with typical sequential expression of K5/6 (red) and K8/18 (green) in the glandular lineage and K5/6 (red) and SMA (pink) in the myoepithelial lineage. The expression of only K5/6 characterizes progenitor cells (asterisks). These cells show a sequential expression of K8/18 with occasional intermediary cells expressing both K5/6 and K8/18 (short arrow) and a number of K8/18-expressing differentiated glandular cells (long arrows). The hollow arrow denotes a myoepithelial cell expressing both K5/K14 and SMA, indicating the myoepithelial differentiation lineage. (f-i) Pleomorphic adenoma of the breast with focal squamous cell metaplasia. (f) H/E-stain with an epithelial nest with focal squamous differentiation. (g-i) isTILT for K5 (pink), K10 (red), and SMA (green) demonstrating squamous lineage differentiation. Merge (g) and single channels (h) for K5 (pink) and (i) for K10 (red). K5-staining occurs in peripheral progenitor cells. Note the gradual transformation of K5-progenitor cells (asterisks) at the periphery via K5 and K10 co-expression (arrows) to K10-positive squamous cells (hollow arrows). 

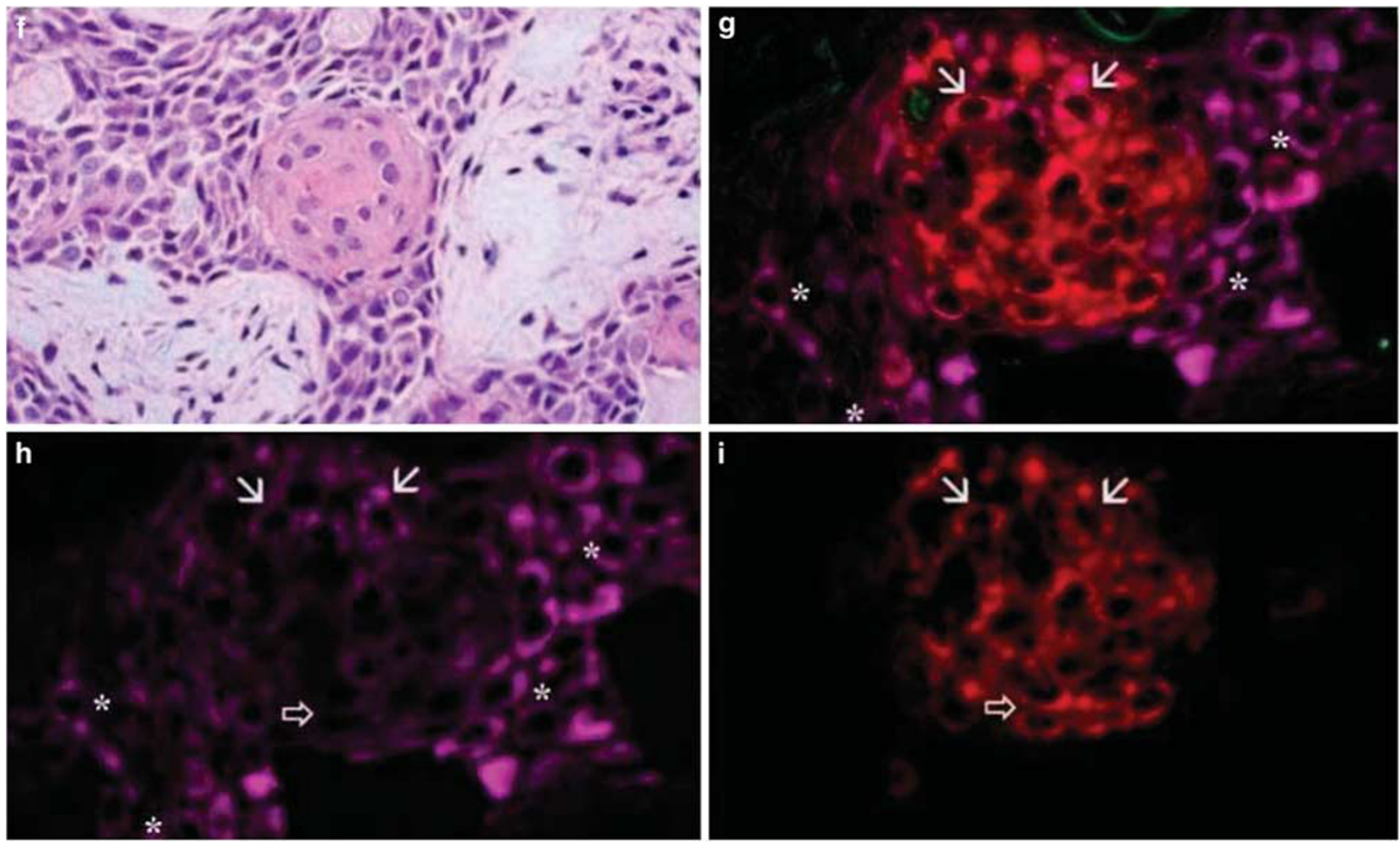

Figure 1 Continued.

\section{Cell Culture}

Tumor cells from a lacrimal gland adenoid cystic carcinoma were maintained in culture as previously described. ${ }^{30,31}$ Briefly, tumor tissue was minced into small pieces and digested in a collagenase solution (1000 U collagenase/ml) (Sigma-Aldrich) for $60 \mathrm{~min}$ at room temperature. The tumor cell suspension was washed twice in culture medium and seeded out in $25 \mathrm{~cm}^{2}$ flasks. Tumor cells from passage 15 were seeded out on 8-well chambers slides (Nunc) and allowed to attach overnight. On the next day, chambers were rinsed briefly with phosphatebuffered saline (PBS) and cells were fixed in methanol for $5 \mathrm{~min}$ at room temperature. Slides were air-dried for $60 \mathrm{~min}$ and subsequently subjected to immunostaining.

\section{MYB-NFIB Fusion Gene Screening}

Total RNA was isolated from cultured adenoid cystic carcinoma cells (passage 15) as previously described. $^{31}$ DNase treated (DNA-freeTM; Ambion, Austin, TX, USA) total RNA was subsequently converted to cDNA using the SuperScriptTM FirstStrand Synthesis System according to the manufacturer's manual (Invitrogen). The MYBNFIB fusion transcripts were amplified by PCR using previously published primer sets. ${ }^{31,32}$ PCR products were gel-purified and sequenced using an ABI PRISM 310 Genetic Analyzer (Applied Biosystems, Foster City, CA, USA).

\section{Results}

\section{Pleomorphic Adenomas}

Four pleomorphic adenomas of the breast, one of which was in a papillary lesion, and four salivary pleomorphic adenomas were analyzed. All tumors showed a characteristic histological appearance with anastomosing cords of epithelial cells and abluminal cells, often with a reticular pattern and spread of these cells into the surrounding 'mesenchymal tissue' with mucoid/myxoid and/or chondroid differentiation (Figure 1a and Supplementary Figure 1a). ${ }^{9,33-35}$ In three tumors (two parotid gland and one breast tumor), we found focal squamous cell metaplasia. Conventional immunohistochemical staining revealed a great variability (Table 1) and the dual nature of the tumors with epithelial and myoepithelial differentiation was confirmed. ${ }^{36,37}$ However, in isTILT-experiments the most remarkable finding in all cases was small groups of cells with basal keratins K5/K14 as the only expressed keratins (Figures $1 \mathrm{~b}-\mathrm{e}$ and Supplementary Figures 1b-d). These cells were also found to co-express p63. In some tumors, these progenitor cells amounted to $15 \%$ of the tumor cell mass. Furthermore, isTILT allowed us to follow the divergent differentiation lineages evolving from these K5/K14-positive cells. Thus, Figures 1b-e and Supplementary Figures $1 \mathrm{~b}-\mathrm{d}$ show triple immunostaining with antibodies for K5/6, K8/18 and SMA in pleomorphic adenomas of the breast and 
Table 1 Immunophenotype of salivary gland-like tumors with myoepithelial differentiation

Pleomorphic adenomas of the breast and the salivary gland

\begin{tabular}{|c|c|c|c|c|c|c|c|c|c|}
\hline \multirow[t]{2}{*}{ Case } & \multirow[t]{2}{*}{ Organ } & \multicolumn{7}{|c|}{ Immunophenotype } & \multirow[t]{2}{*}{ Remark } \\
\hline & & $K 5 / 6$ & K7 & $K 8 / 18$ & K10 & $P 63$ & $S M A$ & Ki67 & \\
\hline 1 & Breast & $90 \%$ & $90 \%$ & $<5 \%$ & $10 \%$ & $90 \%$ & $5 \%$ & $1 \%$ & SCM \\
\hline 2 & Breast & $90 \%$ & NA & $20 \%$ & Negative & $70 \%$ & $10 \%$ & $5 \%$ & - \\
\hline 3 & Breast & $\begin{array}{l}\text { K5/6 40\% } \\
\text { K14 90\% }\end{array}$ & $80 \%$ & $40 \%$ & Negative & $70 \%$ & $20 \%$ & $5 \%$ & - \\
\hline 4 & Breast & $\begin{array}{l}\text { K5/6 60\% } \\
\text { K14 90\% }\end{array}$ & $60 \%$ & $30 \%$ & Negative & $60 \%$ & $20 \%$ & $15 \%$ & - \\
\hline 5 & PG & $90 \%$ & NA & $10 \%$ & Negative & $60 \%$ & $10 \%$ & $5 \%$ & - \\
\hline 6 & PG & $90 \%$ & $80 \%$ & $80 \%$ & $5 \%$ & $70 \%$ & $10 \%$ & $5 \%$ & SCM \\
\hline 7 & PG & $80 \%$ & $60 \%$ & $20 \%$ & Negative & $60 \%$ & $30 \%$ & $1 \%$ & - \\
\hline 8 & PG & $80 \%$ & $60 \%$ & $5 \%$ & $5 \%$ & $60 \%$ & $20 \%$ & $1 \%$ & SCM \\
\hline
\end{tabular}

Epithelial-myoepithelial tumors of the breast and the salivary gland

\begin{tabular}{|c|c|c|c|c|c|c|c|c|c|}
\hline \multirow[t]{2}{*}{ Case } & \multirow{2}{*}{ Organ } & \multicolumn{7}{|c|}{ Immunophenotype } & \multirow{2}{*}{ Remarks } \\
\hline & & $K 5 / 6$ & $K 7$ & K8/18 & $K 10$ & p63 & $S M A$ & Ki67 & \\
\hline 9 & Breast & $\begin{array}{c}\text { K5/6 40\% } \\
\text { K14 5\% }\end{array}$ & $30 \%$ & $40 \%$ & Negative & $70 \%$ (MEC) & $70 \%$ & $5 \%$ & AMT, biphasic SCM \\
\hline 10 & Breast & $80 \%$ & $30 \%$ & $30 \%$ & Negative & $60 \%$ & $50 \%$ & $5 \%$ & AMT, biphasic, lobular type \\
\hline 11 & Breast & $70 \%$ & $60 \%$ & $50 \%$ & Negative & $70 \%$ & $60 \%$ & $10 \%$ & AMT, biphasic; transition to myoepithelial carcinoma $(\mathrm{K} 5 / 6+, \mathrm{SMA}+, \mathrm{p} 63+, \mathrm{K} 8 / 18-)$ \\
\hline 12 & Breast & K5/6 70\% & NA & $25 \%$ & Negative & $60 \%$ & $30 \%$ & $1 \%$ & AMT, biphasic, lobular; associated with sclerosing lesion \\
\hline 13 & Breast & 90 & NA & 50 & Negative & $80 \%$ & $60 \%$ & $25 \%$ & AMT, spindle type, malignant \\
\hline 14 & Breast & $80 \%$ & $20 \%$ & $50 \%$ & Negative & $50 \%$ & $60 \%$ & $5 \%$ & AMT, spinle cell type, malignant \\
\hline 15 & PG & $50 \%$ & $40 \%$ & $30 \%$ & Negative & $50 \%$ & $60 \%$ & $10 \%$ & EMC;biphasic \\
\hline 16 & PG & $20 \%$ & $50 \%$ & $60 \%$ & Negative & $40 \%$ & $50 \%$ & $10 \%$ & EMC;biphasic \\
\hline 17 & Breast & $80 \%$ & Negative & Negative & Negative & $80 \%$ & $70 \%$ & $15 \%$ & Myoepithelial carcinoma \\
\hline
\end{tabular}

ACC of the breast, salivary and lacrinmal gland

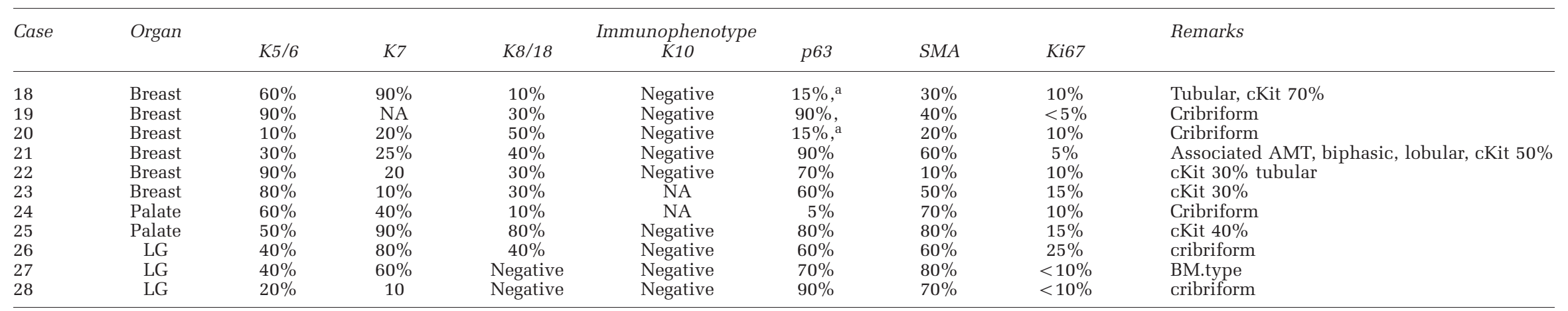

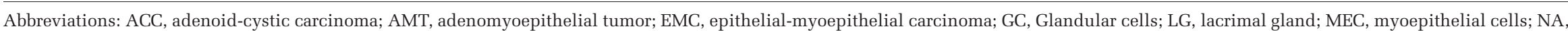
not analyzed; PG, parotid gland; SCM, squamous cell metaplasia.

${ }^{a}$ Notes: periphery. 
salivary gland. Clusters of K5/6-positive cells were identified. In addition, there were also a number of cells with coexpression of K5/6 and K8/18 (intermediary glandular cells) as well as differentiated cells that only expressed the glandular-specific keratins 8/18 (Figures 1c and d). A similar sequential expression of $\mathrm{K} 5$ or $\mathrm{K} 14$ and other lineage markers could also be observed in the myoepithelial (Figures 1a and d and Supplementary Figures 1c and $\mathrm{d}$ ), squamous (Figures $1 \mathrm{f}-\mathrm{i}$ ), and mesenchymal lineages (Supplementary Figure 2). p63-expression was seen only in the myoepithelial and squamous lineages and not in the glandular lineage.

\section{Epithelial-myoepithelial Tumors}

We analyzed six epithelial-myoepithelial tumors of the breast and two of the salivary glands. Four breast tumors and two salivary gland tumors showed the typical biphasic pattern with prominent myoepithelial proliferations intermingled with glandular structures (Figure 2a and Supplementary Figure 3a). Myoepithelial cells with spindled appearance and clear or eosinophilic cytoplasm were evenly distributed in the background. Immunohistochemically, a multilayering of myoepithelial cells was usually observed outside of the glandular cells (Supplementary Figures 3b-d), which were partly surrounded by a deposition of collagen IV- and laminin-positive basement membrane (data not shown). In other cases, we observed a solid proliferation of myoepithelial cells between glandular spaces with irregular formation of basement membrane-like material between the tumor cells (Supplementary Figure 3e). In isTILT experiments, we observed in all tumors K5/K14-positive progenitor cells amounting to about $1 \%$ of the tumor cell population (Figures 2c and d and Supplementary Figure 4). Furthermore, a sequential expression of $\mathrm{K} 5 / \mathrm{K} 14$ and glandular lineage markers K8/18 in glandular cells and K5/K14 and the myoepithelial marker SMA in spindle cells were observed in all
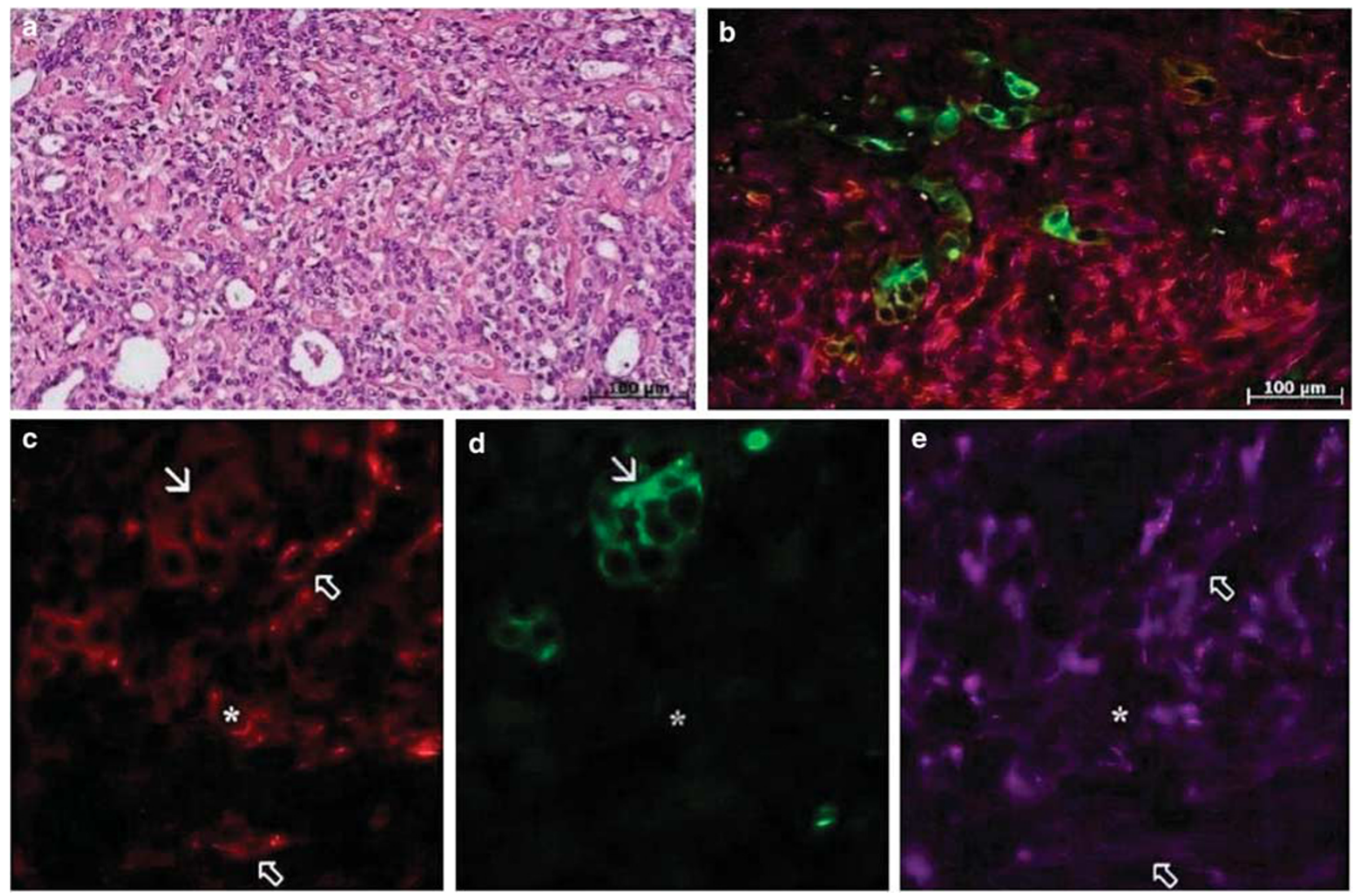

Figure 2 Adenomyoepithelial tumor of the breast. (a) H/E stain of a biphasic tumor with some tubular structures in the lower part of the figure and a predominant proliferation of polygonal myoepithelial cells with clear cytoplasm. Note the reticular basement membrane-like material between the tumor sheets. (b-e) isTILT for basal keratin K14 (red), glandular keratins K8/18 (green), and SMA (pink) demonstrating glandular and myoepithelial differentiation. (b) Merge image. (c-e) Single channels at higher magnification showing glandular structures with expression of glandular keratins 8/18 (green), surrounding spindle cells expressing K14 (red), and SMA (pink). A few cells express only K14 indicating that they are progenitor cells (asterisk). The glandular cells co-express K14 and glandular keratins 8/18 (arrows). There are also cells co-expressing K14 and SMA (hollow arrow) but many myoepithelial cells only express SMA. The sequential expression of basal- and lineage-specific markers indicates the lineage differentiation from K14-positive progenitor cells. (f-i) Adenomyoepithelial tumor of the breast with focal squamous metaplasia. isTILT for K14 (f, green), K10 (g, Cy3), and K5 (h, pink). (i) Merge image. Nuclei are counterstained with DAPI. Note the transition of K5- and/or K14-positive cells to K10-positive squamous cells. Inset in (g): H/E-staining of squamous cell metaplasia in an otherwise typical biphasic AME. 

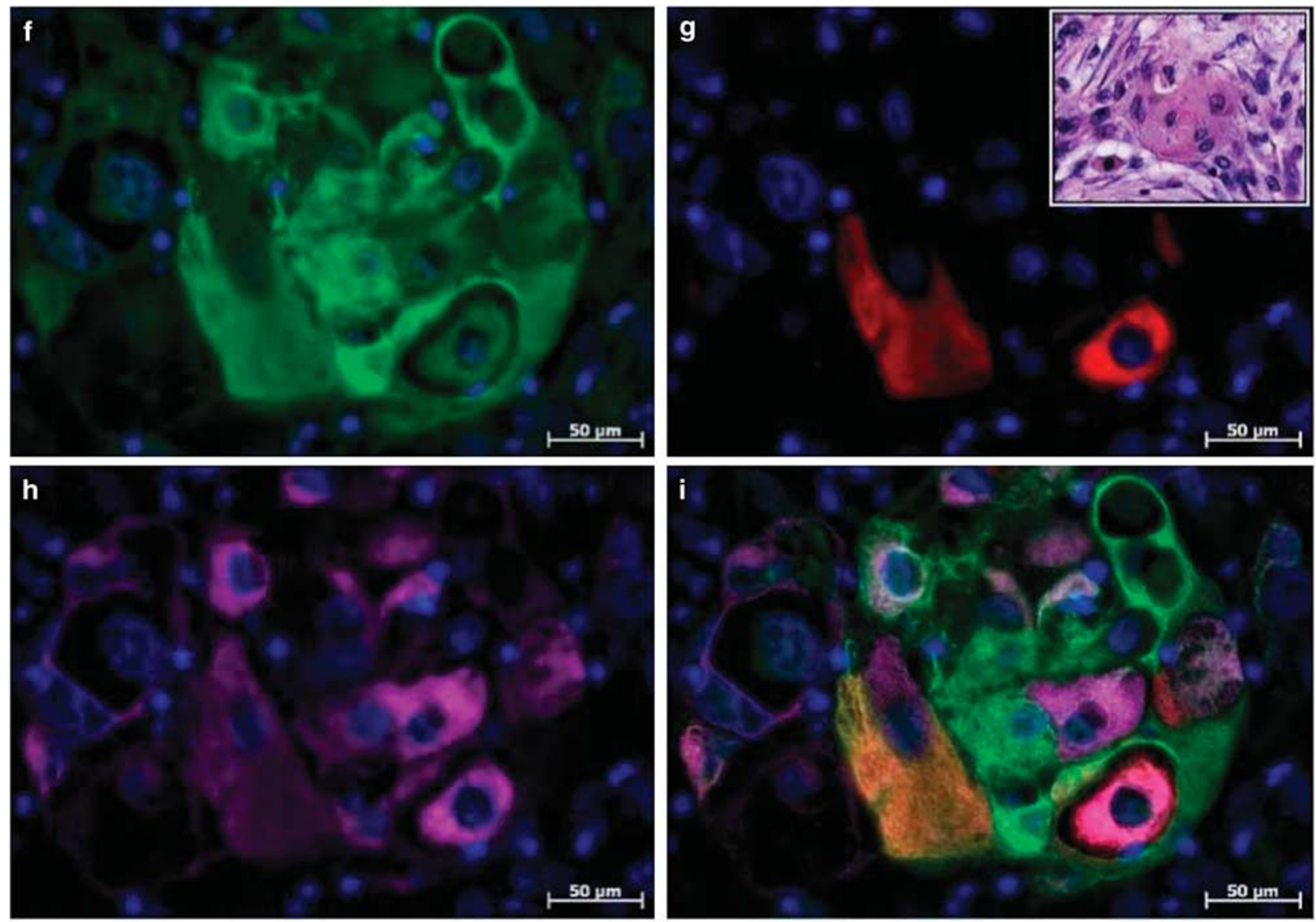

Figure 2 Continued.

tumors investigated (Figures 2c-e and Supplementary Figures 4c-e), indicating the evolution of these two cell lineages from K5/K14 progenitor cells. The same staining pattern could be observed in two cases of malignant adenomyoepithelioma of the breast of the spindle cell type (Supplementary Figure 5). Interestingly, the two adenomyoepitheliomas with spindle cell pattern contained a number of hybrid-cells coexpressing keratins $\mathrm{K} 5 / \mathrm{K} 14, \mathrm{~K} 8 / 18$, and the myoepithelial marker SMA as well as p63. One case of adenomyoepithelioma displayed squamous differentiation evolving from K5 and/or K14-positive progenitor cells (Figures $2 \mathrm{f}-\mathrm{i}$ ).

\section{Myoepithelial Carcinoma (Malignant Myoepithelioma)}

We have found only one convincing case classified as a pure myoepithelial carcinoma, which was included in this series. Monophasic tumors with additional glandular differentiation, as identified immunohistochemically by K8/18 expression, were classified as monophasic adenomyoepitheliomas (see above). The case with pure myoepithelial differentiation contained K5/14-positive cells, which coexpressed the myoepithelial marker SMA
(Supplementary Figure 6). p63 was also highly expressed in these lesions. No other lineage differentiation was observed.

\section{Adenoid Cystic Carcinoma}

Six primary adenoid cystic carcinomas of the breast-, and two salivary and three lacrimal adenoid cystic carcinomas were analyzed. All cases displayed a typical cribriform pattern dominated by basal-like cells. Many pseudoglandular lumina with eosinophilic alcian blue-positive globules and true glandular lumina containing $\mathrm{H} / \mathrm{E}$ basophilic and diastase-PAS-positive secretions were found. The immunohistochemical profile observed in all cases included positivity for $\mathrm{K} 5$ and K14, SMA, K7/K8/18, and p63 (Table 1). The glandular keratins K7/K8/18 were focally found in glandular structures. The glands were nearly always p63-negative, but a number of glandular cells expressed K5/K14. All tumors displayed myoepithelial differentiation, as indicated by coexpression of K5/K14, p63 and SMA. Using isTILT, the cellular hallmark of these tumors was a mixture of few $\mathrm{K} 5 / \mathrm{K} 14$-positive progenitor cells (about 1\% of the tumor cells) in a bulk of cells 
differentiating into myoepithelial cells (positive for K5/K14/SMA/p63) and focally into glandular cells (sequential expression of $\mathrm{K} 5 / \mathrm{K} 14$ and $\mathrm{K} 7 / \mathrm{K} 8 / 18$ ) (Figures 3a-d). The myoepithelial differentiation was observed in basal-like cells and in cells in the vicinity of pseudoglandular spaces that were filled with collagen IV- and laminin-positive hyaline basement membrane-like globules or membranes.

We also studied the cellular composition and differentiation of cultured tumor cells from a lacrimal gland adenoid cystic carcinoma as well as from the primary tumor from which the cells were derived. The cultured cells had a typical epithelial morphology with small to medium-sized, rounded or cuboidal cells. Both the primary tumor and the cultured cells expressed the adenoid cystic carcinoma-specific $M Y B-N F I B$ gene fusion (data not shown). isTILT-analysis revealed that the cultured adenoid cystic carcinoma cells showed the same cellular differentiation pattern as the primary tumor (Figures 3e-h and Supplementary Figure 7).

\section{Normal Breast and Salivary Gland Epithelium}

Based on the assumption that the cellular features of these tumors reflect (mimic) the differentiation potential of their cells of origin, we analyzed the epithelium in both organs using the isTILT experiments described above.

The ducts of both glands contained K5/14-positive progenitor cells, which differentiated to glandular cells (Supplementary Figure 7). However, the interlobular ducts of the breast contained a luminal layer showing a mixture of K5 and/or K14-positive progenitor cells, intermediary glandular cells (K5/ $\mathrm{K} 14$ and $\mathrm{K} 7 / \mathrm{K} 8 / 18$ ) and glandular cells (only K7/8/ 18). In contrast, in striated ducts of the salivary gland, K5/K14-positive progenitor cells could be found only in a basal position which co-expressed p63. The luminal layer contained glandular cells expressing K7 and K8/18. Occasionally, a sequential expression of glandular keratins $\mathrm{K} 7 / \mathrm{K} 8 / 18$ and basal keratins 5/14 could be observed in striated ducts with formation of intermediary (K5/K14 and $\mathrm{K} 7 / \mathrm{K} 8 / 18$ ) and glandular cells (K7/8/18 only). These data clearly speak for a differentiation pathway of glandular duct cells from K5/K14-positive progenitor cells.

\section{qPCR Analyses}

The expressions of basal (K5/K14) and glandular (K7/K8/K18) keratins, epidermal specific squamous keratin (K10), and ACTA2 were studied by qPCR in seven tumors with myoepithelial differentiation. As
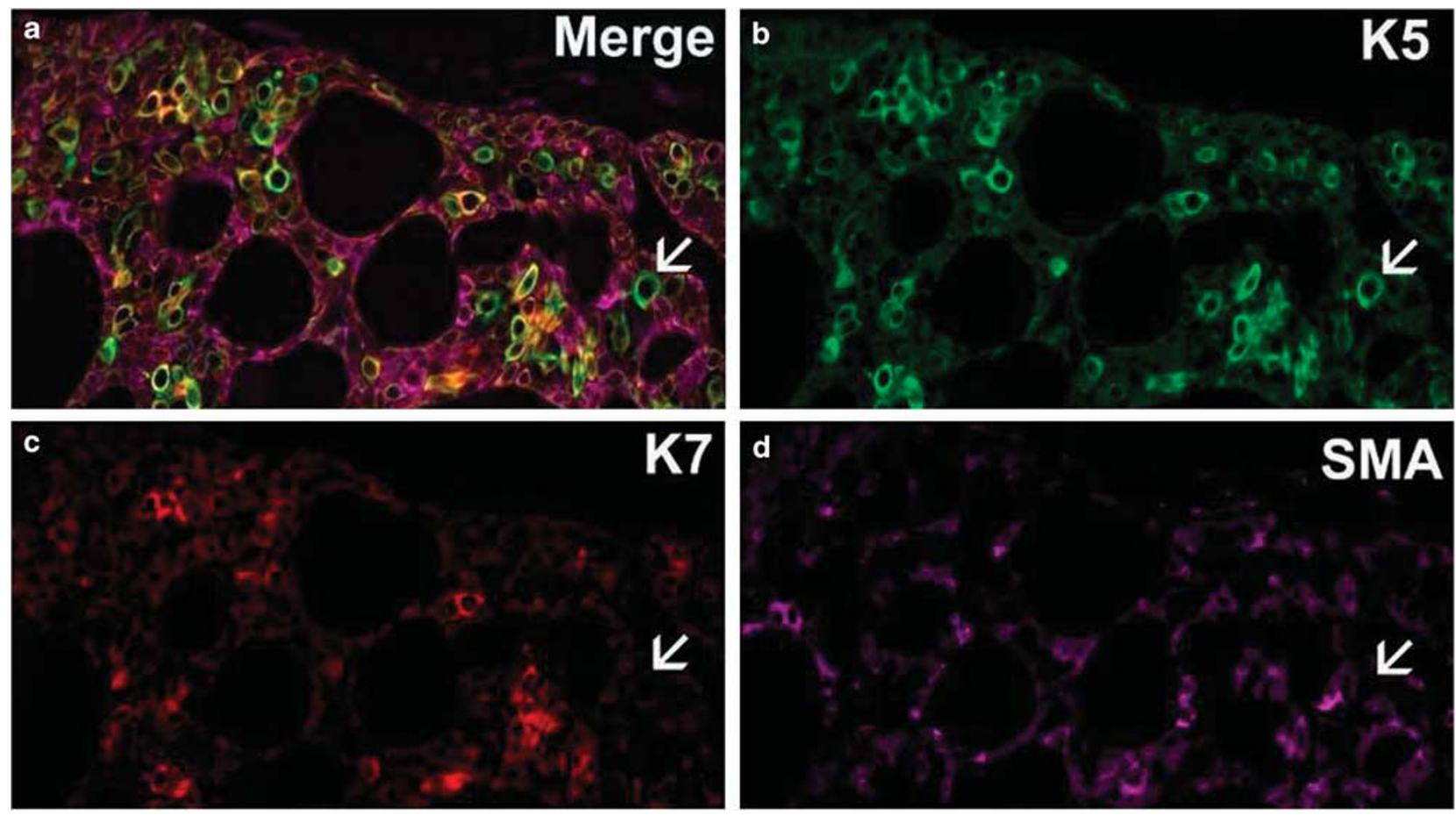

Figure 3 Adenoid cystic carcinoma of the lacrimal gland. isTILT for keratins K5 (green), K7 (red), and SMA (green). (a) Merge image. (b-d) Single channels showing a smaller number of tumor cells co-expressing K5 (green) and K7 (red). The bulk or tumor cells co-express K5 (green) and SMA (pink). Occasionally, cells are observed that only express K5 (arrows). The sequential expression of K5 and K7 on one side and K5 and SMA on the other side indicates the evolution of glandular and myoepithelial cells from K5-positive progenitor cells. (e-h) Cultured tumor cells derived from the adenoid cystic carcinoma shown in (a) demonstrating one K5-positive cell (arrow), and cells co-expressing K5 and K7 (tailed arrows). One cell shows K5 and a weak co-expression of both K7 and SMA (hollow arrow). 

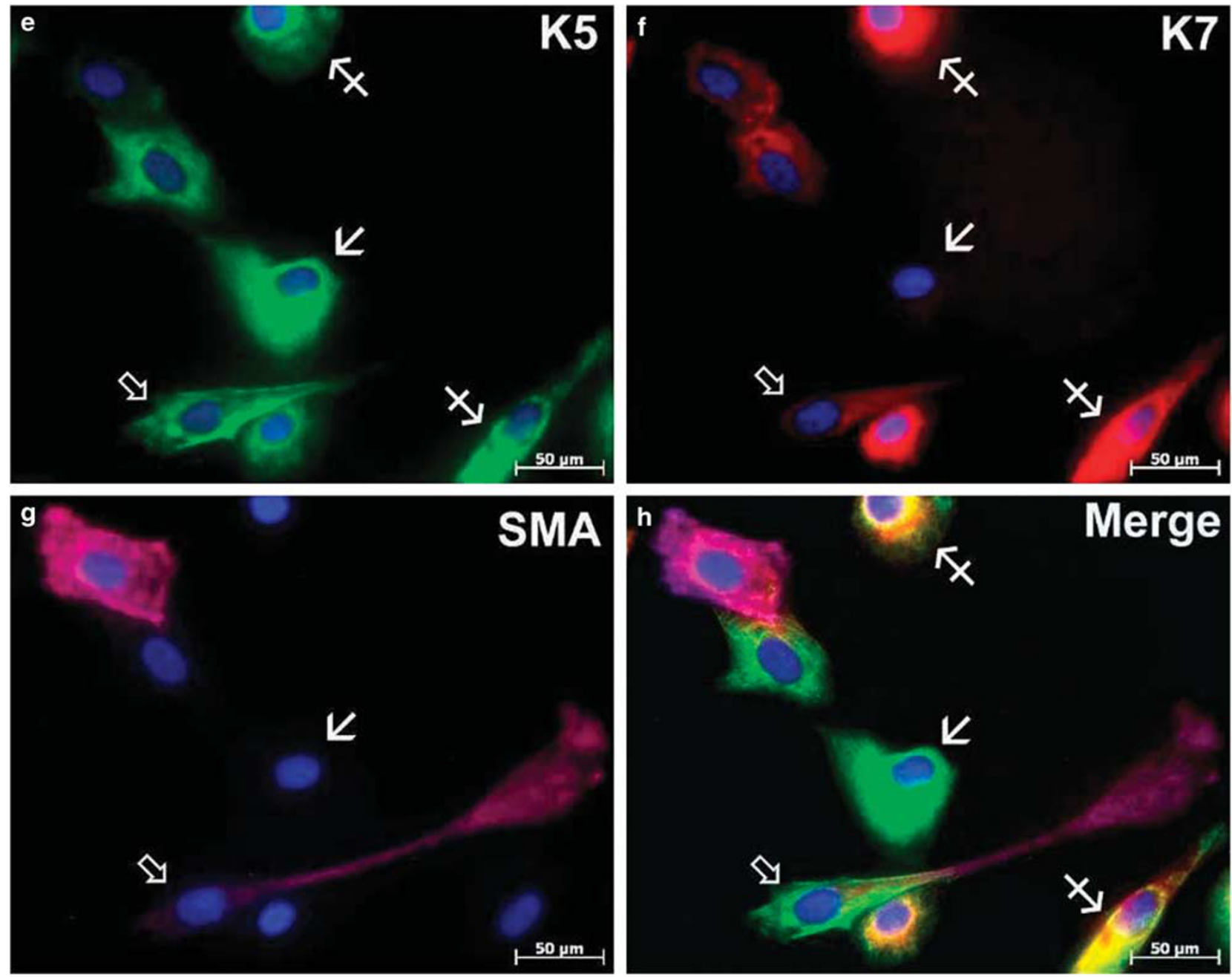

Figure 3 Continued.

shown in Figure 4, we found upregulation of mRNA of both basal and glandular keratins in all tumors compared with normal breast parenchyma. Similarly, the expression of ACTA2 was lower in the tumors compared with normal breast tissue with the exception of one adenomyoepithelioma (lobulated type) and two adenoid cystic carcinomas that showed the highest levels of ACTA2 expression (cases 9, 19 and 23 in Table 1). The expression of the epidermal-specific squamous keratin 10 was, compared with nipple epidermis, very low with a moderate level only in one pleomorphic adenoma of the parotid gland (case 6 in Table 1), which displayed squamous differentiation in H/E and K10 expression in immunostaining. When comparing the RNA and protein expression levels, we found that the RNA-levels of basal and glandular keratins were positively correlated with the immunohistochemical findings. Thus, the RNA data corroborated the immunohistochemical findings implying that these tumors represent basal type tumors with glandular and myoepithelial differentiation.

\section{Discussion}

Here, we present a systematic isTILT and qPCR study of a series of look-alike tumors of the breast and salivary/lacrimal glands with myoepithelial differentiation. In agreement with previous observations, our findings revealed the dual epithelial myoepithelial nature of these lesions, ${ }^{3,38}$ including expression of glandular (luminal) keratins K7/K8/ 18, and myoid markers such as SMA, maspin, CD10, calponin, basal keratins $\mathrm{K} 5 / \mathrm{K} 14$, and p63.16,38-44 Using isTILT, we could demonstrate the cellular organization of these tumors from a novel point of view. Thus, we identified neoplastic cells in all lesions that only expressed the basal keratins $\mathrm{K} 5$ and K14. These cells varied in frequency from only a few percent in adenoid cystic carcinomas and up to $15 \%$ in pleomorphic adenomas and in epithelialmyoepithelial tumors. The K5/K14-positive cells co-expressed p63, and, when they lacked specific lineage markers, they were regarded as neoplastic progenitor cells. Moreover, we provide evidence that 

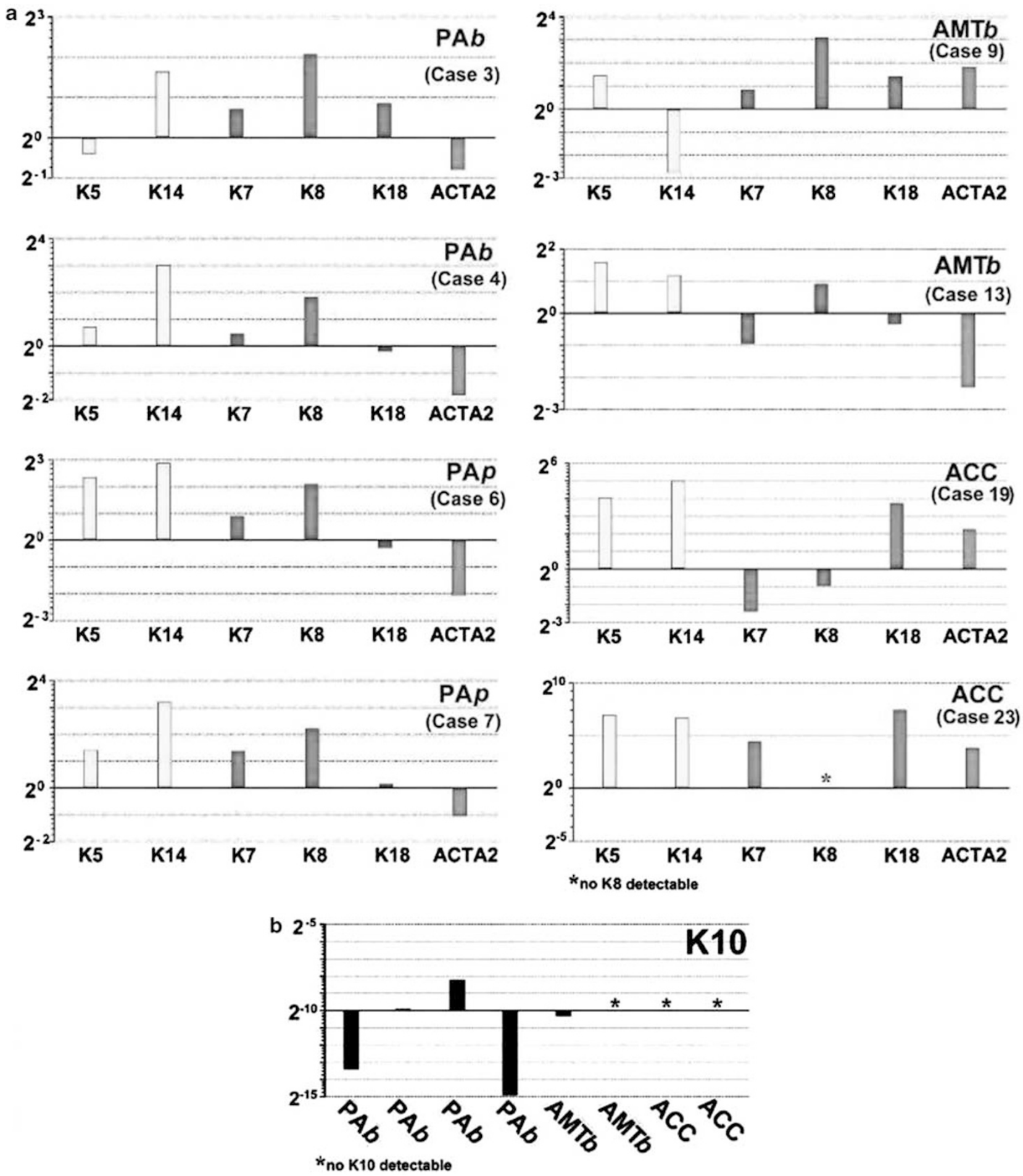

Figure 4 mRNA expression of basal keratins K5 and K14, luminal keratins K7, K8, and K18, squamous keratin K10, and ACTA2 in salivary gland-like tumors with myoepithelial differentiation. The expression of basal and luminal keratins are higher in all tumors tested compared with normal breast parenchyma (zero line). In contrast, the expression of ACTA2 is, with the exception of one adenomyoepithelioma of the breast, lower in the tumors compared with normal breast tissue (zero line).

in the glandular and myoepithelial lineages the basal keratins K5/K14 and the corresponding lineage marker (K8/18 or SMA) are sequentially expressed during differentiation. Eventually, the expression of $\mathrm{K} 5 / \mathrm{K} 14$ is downregulated in these cells and only the lineage specific protein is expressed. Thus, our data strongly indicate that the glandular and myoepithelial cell lineages in these tumors are derived from K5/K14/p63-positive neoplastic progenitor cells. These data raise doubts about the 

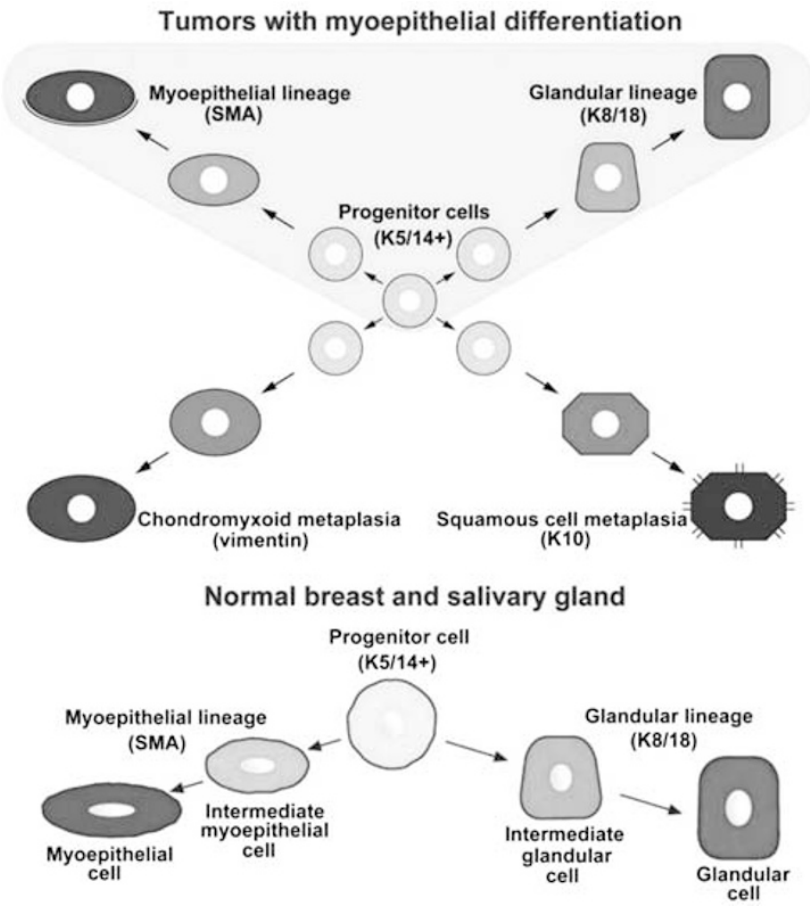

Figure 5 Lineage differentiation model of look-alike tumors with myoepithelial differentiation showing that K5/K14-positive tumor cells are key players in these tumors. K5/K14-positive tumor cells differentiate to glandular and myoepithelial cells. Notably, these cells also give rise to squamous and mesenchymal cells in salivary gland-like breast tumors.

current concept that in these lesions the luminal cell types arise from differentiation of myoepithelial cells. $^{45,46}$ In one case of lacrimal gland adenoid cystic carcinoma, we had access to both cultured MYB-NFIB fusion-positive adenoid cystic carcinoma-cells and the corresponding primary tumor. The immunofluorescence stainings of the cultured cells fully corroborated the results of the primary tumor. They also confirmed the results of our isTILT-experiments, which revealed glandularmyoepithelial hybrid cells with co-expression of both glandular keratins $\mathrm{K} 7 / \mathrm{K} 8 / 18$ and myoid markers such as SMA. Interestingly, the myoepithelial differentiation was usually associated with the formation of collagen IV- and laminin-positive basement membrane material, which has been shown to be a diagnostically important feature in adenoid cystic carcinoma. ${ }^{42}$

It is well known that look-alike tumors with myoepithelial differentiation of both the breast and salivary glands may show areas of mesenchymal, squamous, and/or sebaceous differentiation. ${ }^{41,47-50}$ It has been suggested that squamous and mesenchymal elements are derived from myoepithelial cells. ${ }^{51}$ Using isTILT, we found evidence for the origin of the K10-positive squamous lineage from K5/K14positive progenitor cells, indicating striking similarities to normal squamous differentiation. Finally, sequential expression of $\mathrm{K} 5 / \mathrm{K} 14$ and vimentin as mesenchymal marker in tumor cells of pleomorphic adenomas (in the absence of SMA or other myoepithelial markers) with chondroid changes, support the view that K5/K14-positive cells gradually differentiate to mesenchymal tissues in these tumors. These observations are in line with the view that pleomorphic adenomas arise from a single-cell type capable of divergent differentiation. ${ }^{9}$ We believe that our findings might also explain how at least a part of metaplastic carcinomas with extracellular matrix of the breast may develop.

Based on the data discussed above, we propose a lineage differentiation model of look-alike tumors of the breast and salivary glands with myoepithelial differentiation (Figure 5) using the epithelial cell models of human breast epithelium, ${ }^{52-55}$ eccrine gland ducts, ${ }^{56}$ and squamous epithelium, ${ }^{57}$ as a reference. All our tumors contained K5/K14-positive tumor cells that seem to constitute the progeny cells of the different cell lineages observed in these tumors. Interestingly, K5/K14-positive tumor cells corresponded to K5/K14-positive normal cells of large/nipple and striated/interlobular ducts of breast/salivary gland as well as to the basal layer of squamous epithelium (Boecker et al, manuscript in preparation).

However, despite the similarities between these look-alike tumors of the breast and salivary gland, many questions remain unresolved. Thus, most epithelial-myoepithelial tumors of the breast ${ }^{58}$ are thought to possess only a borderline malignant potential, ${ }^{43,59-62}$ whereas the same tumor in salivary glands, known as epithelial myoepithelial carcinoma, are clearly malignant. ${ }^{45,63-66}$ Pure myoepithelial tumors have only rarely been reported in the breast ${ }^{3,67-71}$ and account for about $3 \%$ of all tumors of salivary glands. ${ }^{72-76}$ The differential diagnosis include spindle cell tumors with glandular ${ }^{72,77-79}$ and/or squamous differentiation, ${ }^{67}$ spindle cell adenocarcinomas, ${ }^{80-84}$ and mesenchymal tumors. ${ }^{37}$ Here, we have only studied one malignant myoepithelioma of the breast, which expressed K5/K14 and the myoid marker SMA, but not, or only focally and rather feebly, glandular keratins K7/K8/K18 and/or keratin K10.

Adenoid cystic carcinomas of both the breast and salivary glands are morphologically, immunophenotypically (see above), and genetically very similar. Thus, they are both characterized by the same recurrent $\mathrm{t}(6 ; 9)$ translocation resulting in the $M Y B$ NFIB gene fusion. ${ }^{31,85}$ Overexpression of the MYB oncogene is a hallmark of adenoid cystic carcinoma irrespective of anatomical location. ${ }^{32,85,86}$ Despite these similarities, there are important differences between these tumors. Thus, adenoid cystic carcinomas of the breast are very rare $(0.1-1 \%$ of all breast cancers ${ }^{38}$ ) and have an excellent prognosis whereas adenoid cystic carcinomas of the salivary glands account for about $10 \%$ of epithelial tumors of the salivary glands and are a highly aggressive disease with a high recurrence rate and long-term 
poor survival. ${ }^{87,88}$ The differences in clinical behavior are only partly known. Recent studies using high-resolution array-CGH have shown that adenoid cystic carcinomas of the breast have very few or no recurrent copy number alterations in line with their non-aggressive clinical appearance. ${ }^{89}$ In contrast, salivary gland adenoid cystic carcinomas have multiple recurrent copy number alterations some of which are associated with a poor prognosis. ${ }^{90,91}$

Dedifferentiation and progression to high-grade lesions (no specific type grade 3 , malignant myoepithelial, or of mixed epithelial-myoepithelial type) have been described both in salivary gland and breast tumors. ${ }^{59,71,92-97}$ It has been suggested that new genetic alterations gradually accumulate in subclones of these tumors leading to clonal evolution and disease progression. ${ }^{31,90-92}$ Based on our proposed lineage differentiation model (Figure 5), it seems likely that in addition to specific genetic alterations, the cell lineage and the stage of differentiation of the cells undergoing 'dedifferentiation' are important factors that might influence this process.

A key to the understanding of proliferative diseases is the knowledge about the corresponding normal tissues. Our isTILT studies revealed that normal breast and salivary glands show striking similarities in their cellular composition. Both glands contain K5/K14/p63-positive progenitor cells, which give rise to glandular cells with subsequent downregulation of basal keratins/p63 and upregulation of glandular keratins K7/K8/18. Furthermore, it has been demonstrated for breast tissue that the myoepithelial cells originate (embryologically, in transplantation studies, and during physiological regeneration) from $\mathrm{K} 5$ and/or K14-positive progenitors ${ }^{52,53,55}$ that co-express p63. ${ }^{16}$ Our isTILT data provide support for similar cellular differentiation processes in the salivary gland (Boecker et al, manuscript in preparation). Based on these observations, we suggest that this unique population of $\mathrm{K} 5 / \mathrm{K} 14$ and p63-positive progenitor cells of breast, salivary, and lacrimal glands form a core cell population that can spawn these different tumor phenotypes.

\section{Acknowledgements}

Part of this study was supported by a grants from the Swedish Cancer Society and BioCARE-a National Strategic Research Program at University of Gothenburg.

\section{Disclosure/conflict of interest}

The authors declare no conflict of interest.

\section{References}

1 Wick MR, Ockner DM, Mills SE, et al. Homologous carcinomas of the breasts, skin, and salivary glands. A histologic and immunohistochemical comparison of ductal mammary carcinoma, ductal sweat gland carcinoma, and salivary duct carcinoma. Am J Clin Pathol 1998;109:75-84.

2 Foschini MP, Pizzicannella G, Peterse JL, et al. Adenomyoepithelioma of the breast associated with lowgrade adenosquamous and sarcomatoid carcinomas. Virchows Arch 1995;427:243-250.

3 Pia-Foschini M, Reis-Filho JS, Eusebi V, et al. Salivary gland-like tumours of the breast: surgical and molecular pathology. J Clin Pathol 2003;56:497-506.

4 Eveson JW, Auclair PL, Gnepp DR, et al. Tumours of the salivary glands: introduction, In: Barnes L, Eveson JW, Reichert P, Sidransky D (eds) Pathology and Genetics of Head and Neck Tumours. IARC Press: Lyon; 2005, pp 212-215.

5 Sapino A, Sneige N, Euseby V. Adenoid cystic carcinoma, In: Lakhani SR, Ellis IO, Schnitt SJ, Tan $\mathrm{PH}$, van de Vijver MJ (eds) WHO Classification of Tumors of the Breast. IARC: Lyon; 2012, pp 56-57.

6 Tavassoli FA, Eusebi V. Tumors of the Mammary Gland. American Registry of Pathology: Washington, DC, USA; 2009, pp 212-260.

7 Foschini MP, Simpson JF, O’Malley FO. Ductal adenoma, In: Lakhani SR, Ellis IO, Schnitt SJ, Tan $\mathrm{PH}$, van de Vijver MJ (eds) WHO Classification of Tumors of the Breast. IARC: Lyon; 2012, pp 117-118.

8 Schmitt F, Tan PH, Dabbs S, et al. Myoepithelial and epithelial-myoepithelial lesions, In: Lakhani SR, Ellis IO, Schnitt SJ, Tan PH, van de Vijver MJ (eds) WHO Classification of tumors of the breast. IARC: Lyon; 2012, pp 119-123.

9 Diaz NM, McDivitt R, Wick MR. Pleomorphic adenoma of the breast: a clinicopathologic and immunohistochemical study of 10 cases. Hum Pathol 1991;22: 1206-1214.

10 Van Hoeven KH, Drudis T, Cranor ML, et al. Low-grade adenosquamous carcinoma of the breast. A clinocopathologic study of 32 cases with ultrastructural analysis. Am J Surg Pathol 1993;17:248-258.

11 Rosen PP. Rosen's Breast Pathology, 3rd edn. Wolters Kluwer, Lippincott Wiliams and Wilkins: Philadelphia, PA, USA; 2009, pp 56-57, 117-118, 119-123.

12 Moll R, Divo M, Langbein L. The human keratins: biology and pathology. Histochem Cell Biol 2008;129:705-733.

13 Moll R, Krepler R, Franke WW. Complex cytokeratin polypeptide patterns observed in certain human carcinomas. Differentiation 1983;23:256-269.

14 Moll R. Cytokeratins as markers of differentiation in the diagnosis of epithelial tumors. Subcell Biochem 1998;31:205-262.

15 Reis-Filho JS, Schmitt FC. Taking advantage of basic research: p63 is a reliable myoepithelial and stem cell marker. Adv Anat Pathol 2002;9:280-289.

16 Reis-Filho JS, Simpson PT, Martins A, et al. Distribution of p63, cytokeratins 5/6 and cytokeratin 14 in 51 normal and 400 neoplastic human tissue samples using TARP-4 multi-tumor tissue microarray. Virchows Arch 2003;443:122-132.

17 Di Tommaso L, Pasquinelli G, Damiani S. Smooth muscle cell differentiation in mammary stromo-epithelial lesions with evidence of a dual origin: stromal 
myofibroblasts and myoepithelial cells. Histopathology 2003;42:448-456.

18 Gusterson BA, Warburton MJ, Mitchell D, et al. Distribution of myoepithelial cells and basement membrane proteins in the normal breast and in benign and malignant breast diseases. Cancer Res 1982; 42:4763-4770.

19 Yeh IT, Mies C. Application of immunohistochemistry to breast lesions. Arch Pathol Lab Med 2008;132: 349-358.

20 Barnes L, Tse LLY, Hunt JL, et al. Tumours of the hypopharinx, larinx and trachea: Introduction. In: Barnes L, Eveson JW, Reichert P, Sidransky D (eds) Pathology and Genetics of Head and Neck Tumours. IARC Press: Lyon; 2005, pp 111-117.

21 El-Naggar A, Huvos AG. Adenoid cystic carcinoma, In: Barnes L, Eveson JW, Reichert P, Sidransky D (eds) Pathology and Genetics of Head and Neck Tumours. IARC Press: Lyon; 2005, pp 221-222.

22 Fonseca I, Soares J. Epithelial-myoepithelial carcinoma, In: Barnes L, Eveson JW, Reichert P, Sidransky D (eds) Pathology and Genetics of Head and Neck Tumours. IARC Press: Lyon; 2005, pp 225-226.

23 Skalova A, Jäkel KT. Myoepithelial carcinoma, In: Barnes L, Eveson JW, Reichert P, Sidransky D (eds) Tumours of the Hypopharinx, Larinx and Trachea: Introduction. IARC Press: Lyon; 2005, pp 240-241.

24 Gnepp DR. Metastasizing pleomorphic adenoma, In: Barnes L, Eveson JW, Reichert P, Sidransky D (eds) Pathology and Genetics of Head and Neck Tumours. IARC Press: Lyon; 2005, pp 245-246.

25 Eveson JW, Kusafuka K, Stenman G, et al. Pleomorphic adenoma, In: Barnes L, Eveson JW, Reichert P, Sidransky D (eds) Pathology and Genetics of Head and Neck Tumours. IARC Press: Lyon; 2005, pp 254-258.

26 Cardesa A, Alos L. Myoepithelioma, In: Barnes L, Eveson JW, Reichert P, Sidransky D (eds) Pathology and Genetics of Head and Neck Tumours. IARC Press: Lyon; 2005, pp 259-260.

27 Buchwalow IB, Boecker W. Immunohistochemistry: Basics and Methods. Springer: Heidelberg, Dordrecht, London, New York; 2010, pp 19-30, 69-76, 109-128.

28 Buchwalow IB, Minin EA, Boecker W. A multicolor fluorescence immunostaining technique for simultaneous antigen targeting. Acta Histochem 2005;107:143-148.

29 Brown JK, Pemberton $\mathrm{AD}$, Wright $\mathrm{SH}$, et al. Primary antibody-Fab fragment complexes: a flexible alternative to traditional direct and indirect immunolabeling techniques. J Histochem Cytochem 2004;52: 1219-1230.

30 Nordkvist A, Gustafsson H, Juberg-Ode $\mathrm{M}$, et al. Recurrent rearrangements of 11q14-22 in mucoepidermoid carcinoma. Cancer Genet Cytogenet 1994;74: 77-83.

31 Persson H, Kvist A, Vallon-Christersson J, et al. The non-coding RNA of the multidrug resistance-linked vault particle encodes multiple regulatory small RNAs. Nat Cell Biol 2009;11:1268-1271.

32 Brill LB 2nd, Kanner WA, Fehr A, et al. Analysis of MYB expression and MYB-NFIB gene fusions in adenoid cystic carcinoma and other salivary neoplasms. Mod Pathol 2011;24:1169-1176.

33 Moran CA, Suster S, Carter D. Benign mixed tumors (pleomorphic adenomas) of the breast. Am J Surg Pathol 1990;14:913-921.
34 Williams RW, Leach WB. Mixed tumor of female breast of unusual duration and size. South Med J 1975;68: 97-100.

35 Soreide JA, Anda O, Eriksen L, et al. Pleomorphic adenoma of the human breast with local recurrence. Cancer 1988;61:997-1001.

36 Tavassoli FA, Devilee PWHO. Classification of Tumours, Tumours of the Breast and Female Genital Organs, In: Tavassoli FA, Devilee P (eds), IARC Press: Lyon, 2003.

37 Lakhani SR, Ellis IO, Schnitt SJ, et al. WHO Classification of Tumors of the Breast, 4th edn. IARC Press: Lyon, 2012.

38 Foschini MP, Krausz T. Salivary gland-type tumors of the breast: a spectrum of benign and malignant tumors including "triple negative carcinomas" of low malignant potential. Semin Diagn Pathol 2010;27:77-90.

39 Reis-Filho JS, Milanezi F, Silva P, et al. Maspin expression in myoepithelial tumors of the breast. Pathol Res Pract 2001;197:817-821.

40 Kasami M, Olson SJ, Simpson JF, et al. Maintenance of polarity and a dual cell population in adenoid cystic carcinoma of the breast: an immunohistochemical study. Histopathology 1998;32:232-238.

41 Lamovec J, Us-Krasovec M, Zidar A, et al. Adenoid cystic carcinoma of the breast: a histologic, cytologic, and immunohistochemical study. Semin Diagn Pathol 1989;6:153-164.

42 Marchio C, Weigelt B, Reis-Filho JS. Adenoid cystic carcinomas of the breast and salivary glands (or 'The strange case of Dr Jekyll and Mr Hyde' of exocrine gland carcinomas). J Clin Pathol 2010;63:220-228.

43 McLaren BK, Smith J, Schuyler PA, et al. Adenomyoepithelioma: clinical, histologic, and immunohistologic evaluation of a series of related lesions. Am J Surg Pathol 2005;29:1294-1299.

44 Moritani S, Kushima R, Sugihara H, et al. Availability of CD10 immunohistochemistry as a marker of breast myoepithelial cells on paraffin sections. Mod Pathol 2002;15:397-405.

45 Hamperl H. The myothelia (myoepithelial cells). Normal state; regressive changes; hyperplasia; tumors. Curr Top Pathol 1970;53:161-220.

46 Loose JH, Patchefsky AS, Hollander IJ, et al. Adenomyoepithelioma of the breast. A spectrum of biologic behavior. Am J Surg Pathol 1992;16:868-876.

47 Tavassoli FA, Norris HJ. Mammary adenoid cystic carcinoma with sebaceous differentiation. A morphologic study of the cell types. Arch Pathol Lab Med 1986;110:1045-1053.

48 Hungermann D, Buerger $\mathrm{H}$, Oehlschlegel C, et al. Adenomyoepithelial tumours and myoepithelial carcinomas of the breast-a spectrum of monophasic and biphasic tumours dominated by immature myoepithelial cells. BMC Cancer 2005;5:92.

49 Lim SK, Kovi J, Warner OG. Adenoid cystic carcinoma of breast with metastasis: a case report and review of the literature. J Natl Med Assoc 1979;71:329-330.

50 Qizilbash AH, Patterson MC, Oliveira KF. Adenoid cystic carcinoma of the breast. Light and electron microscopy and a brief review of the literature. Arch Pathol Lab Med 1977;101:302-306.

51 Rosen PP. Rosen's Breast Pathology, 3rd edn. Wolters Kluwer, Lippincott Wiliams and Wilkins: Philadelphia, PA, USA; 2009, pp 92.

52 Boecker W, Moll R, Poremba C, et al. Common adult stem cells in the human breast give rise to glandular 
and myoepithelial cell lineages: a new cell biological concept. Lab Invest 2002;82:737-746.

53 Dontu G, Al Hajj M, Abdallah WM, et al. Stem cells in normal breast development and breast cancer. Cell Prolif 2003;36(Suppl 1):59-72.

54 Prat A, Perou CM. Mammary development meets cancer genomics. Nat Med 2009;15:842-844.

55 Van Keymeulen A, Rocha AS, Ousset M, et al. Distinct stem cells contribute to mammary gland development and maintenance. Nature 2011;479:189-193.

56 Langbein L, Cribier B, Schirmacher P, et al. New concepts on the histogenesis of eccrine neoplasia from keratin expression in the normal eccrine gland, syringoma and poroma. Br J Dermatol 2008;159: 633-645.

57 Moll R, Franke WW, Schiller DL, et al. The catalog of human cytokeratins: patterns of expression in normal epithelia, tumors and cultured cells. Cell 1982;31:11-24.

58 Hamperl H. The myothelia (myoepithelial cells). Normal state; regressive changes; hyperplasia; tumors. Curr Top Pathol 1970;53:161-120.

59 Rosen PP. Adenomyoepithelioma of the breast. Hum Pathol 1987;18:1232-1237.

60 Tavassoli FA. Myoepithelial lesions of the Breast. Myoepitheliosis, adenomyoepithelioma, and myoepithelial carcinoma. Am J Surg Pathol 1991;15:554-568.

61 Weidner N, Levine JD. Spindle-cell adenomyoepithelioma of the breast. A microscopic, ultrastructural, and immunocytochemical study. Cancer 1988;62: 1561-1567.

62 Loose JH, Patchefsky AS, Hollander IJ, et al. Adenomyoepithelioma of the breast. A spectrum of biologic behavior. Am J Surg Pathol 1992;16:868-876.

63 Cho KJ, el-Naggar AK, Ordonez NG, et al. Epithelial-myoepithelial carcinoma of salivary glands. A clinicopathologic, DNA flow cytometric, and immunohistochemical study of Ki-67 and HER-2/neu oncogene. Am J Clin Pathol 1995;103:432-437.

64 Corio RL, Sciubba JJ, Brannon RB, et al. Epithelialmyoepithelial carcinoma of intercalated duct origin. A clinicopathologic and ultrastructural assessment of sixteen cases. Oral Surg Oral Med Oral Pathol 1982;53:280-287.

65 Donath K, Seifert G, Schmitz R. Diagnosis and ultrastructure of the tubular carcinoma of salivary gland ducts. Epithelial-myoepithelial carcinoma of the intercalated ducts. Virchows Arch A Pathol Pathol Anat 1972;356:16-31.

66 Luna MA, Ordonez NG, Mackay B, et al. Salivary epithelial-myoepithelial carcinomas of intercalated ducts: a clinical, electron microscopic, and immunocytochemical study. Oral Surg Oral Med Oral Pathol 1985;59:482-490.

67 Lakhani SR, O’Hare MJ, Monaghan P, et al. Malignant myoepithelioma (myoepithelial carcinoma) of the breast: a detailed cytokeratin study. J Clin Pathol 1995;48:164-167.

68 Thorner PS, Kahn HJ, Baumal R, et al. Malignant myoepithelioma of the breast. An immunohistochemical study by light and electron microscopy. Cancer 1986;57:745-750.

69 Jennens RR, Rosenthal MA, Gonzales M. Metastatic myoepithelioma of the breast. ANZ J Surg 2004; 74:1135-1137.

70 Shiraishi T, Nakayama T, Fukutome K, et al. Malignant myoepithelioma of the breast metastasizing to the jaw. Virchows Arch 1999;435:520-523.
71 Chen PC, Chen CK, Nicastri AD, et al. Myoepithelial carcinoma of the breast with distant metastasis and accompanied by adenomyoepitheliomas. Histopathology 1994;24:543-548.

72 Lee AH, Rakha EA, Hodi Z, et al. Re-audit of revised method for assessing the mitotic component of histological grade in needle core biopsies of invasive carcinoma of the breast. Histopathology 2012;60: 1166-1167.

73 Ellis GL, Auclair PL. Tumours of the salivary glands, 3rd edn. Armed Forces Institute of Pathology: Washington DC, USA, 1996.

74 Cardesa A, Alos L. Myoepithelioma, In: Barnes L (ed) WHO: Head and Neck Tumours. IARS Press: Lyon; 2005, pp 259-260.

75 Seifert G, Sobin LH. Histological Typing of Salivary Gland Tumours, 2nd edn. Springer: Berlin, Germany, 1991.

76 Nagao T, Sugano I, Ishida Y, et al. Salivary gland malignant myoepithelioma: a clinicopathologic and immunohistochemical study of ten cases. Cancer 1998;83:1292-1299.

77 Rasbridge SA, Millis RR. Adenomyoepithelioma of the breast with malignant features. Virchows Arch 1998;432:123-130.

78 Ahmed AA, Heller DS. Malignant adenomyoepithelioma of the breast with malignant proliferation of epithelial and myoepithelial elements: a case report and review of the literature. Arch Pathol Lab Med 2000;124:632-636.

79 Sugano I, Nagao T, Tajima Y, et al. Malignant adenomyoepithelioma of the breast: a non-tubular and matrix-producing variant. Pathol Int 2001; 51:193-199.

80 Lakhani SR, O’Hare MJ. The mammary myoepithelial cell-Cinderella or ugly sister. Breast Cancer Res 2001;3:1-4.

81 Jones C, Foschini MP, Chaggar R, et al. Comparative genomic hybridization analysis of myoepithelial carcinoma of the breast. Lab Invest 2000;80:831-836.

82 Jones C, Nonni AV, Fulford L, et al. CGH analysis of ductal carcinoma of the breast with basaloid/myoepithelial cell differentiation. Br J Cancer 2001;85: 422-427.

83 Tsuda H, Takarabe T, Hasegawa T, et al. Myoepithelial differentiation in high-grade invasive ductal carcinomas with large central acellular zones. Hum Pathol 1999;30:1134-1139.

84 Damiani S, Riccioni L, Pasquinelli G, et al. Poorly differentiated myoepithelial cell rich carcinoma of the breast. Histopathology 1997;30:542-548.

85 Stenman G, Andersson MK, Andren Y. New tricks from an old oncogene: gene fusion and copy number alterations of MYB in human cancer. Cell Cycle 2010;9:2986-2995.

86 Mitani Y, Li J, Rao PH, et al. Comprehensive analysis of the MYB-NFIB gene fusion in salivary adenoid cystic carcinoma: incidence, variability, and clinicopathologic significance. Clin Cancer Res 2010;16:4722-4731.

87 Lakhani M, Saiful F, Bekheit S, et al. Use of intracardiac echocardiography for early detection of phrenic nerve injury during cryoballoon pulmonary vein isolation. J Cardiovasc Electrophysiol 2012; 23:874-876.

88 Billings KR, Fu YS, Calcaterra TC, et al. Hemangiopericytoma of the head and neck. Am J Otolaryngol 2000;21:238-243. 
89 Wetterskog D, Lopez-Garcia MA, Lambros MB, et al. Adenoid cystic carcinomas constitute a genomically distinct subgroup of triple-negative and basal-like breast cancers. J Pathol 2012;226:84-96.

90 Rao PH, Roberts D, Zhao YJ, et al. Deletion of 1p32-p36 is the most frequent genetic change and poor prognostic marker in adenoid cystic carcinoma of the salivary glands. Clin Cancer Res 2008;14:5181-5187.

91 Persson M, Andren Y, Moskaluk CA, et al. Clinically significant copy number alterations and complex rearrangements of MYB and NFIB in head and neck adenoid cystic carcinoma. Genes Chromosomes Cancer 2012;51:805-817.

92 Altemani A, Martins MT, Freitas L, et al. Carcinoma ex pleomorphic adenoma (CXPA): immunoprofile of the cells involved in carcinomatous progression. Histopathology 2005;46:635-641.

93 Hernmann ME, Bratthauer GL, Stamatakos MD, et al. Maligancies arising in adenomaoepithelioma (AME) of breast: clinical outcome and immunohistochemical characterization [abstract]. Mod Pathol 2003;16:33a.

94 Michal M, Baumruk L, Burger J, et al. Adenomyoepithelioma of the breast with undifferentiated carcinoma component. Histopathology 1994;24: 274-276.

95 Saarto T, Blomqvist C, Risteli J, et al. Aminoterminal propeptide of type I procollagen (PINP) correlates to bone loss and predicts the efficacy of antiresorptive therapy in pre- and post-menopausal non-metastatic breast cancer patients. Br J Cancer 1998;78: $240-245$.

96 Simpson RH, Cope N, Skalova A, et al. Malignant adenomyoepithelioma of the breast with mixed osteogenic, spindle cell, and carcinomatous differentiation. Am J Surg Pathol 1998;22:631-636.

97 Van Dorpe J, De Pauw A, Moerman P. Adenoid cystic carcinoma arising in an adenomyoepithelioma of the breast. Virchows Arch 1998;432:119-122.

Supplementary Information accompanies the paper on Modern Pathology website (http://www.nature.com/ modpathol) 